J Perinat. Med. $10(1982) 203$

\section{FHR short and long-term variability associated with fetal breathing}

\author{
M. Campogrande, M. G. Alemanno, E. Viora, S. Bussolino
}

Institute of Gynaecology and Obstetrics Clinic, Department of Gynaecologic and Obstetric Pathology (Head: Prof. L. Gagliardi) University of Turin/Italy

\section{Introduction}

Investigations of the influence of fetal breathing movements (FBM) upon the fetal heart rate (FHR) have been performed on fetal lambs by FouRON et al. [7], DAlton et al. [3], and on monkey fetuses by MARTIN et al. [10] and ADAmsons et al. [1]. They found that fetal breathing was associated with an increase in heart rate variability, while mean heart rate changed unpredictably, along with a respiratory sinus arrhythmia. So far only three groups have published studies in which both fetal breathing and the FHR have been recorded simultaneously in the human fetuses: TIMOR-Tritsch et al. [12], WhEELER et al. [13] and DAWEs et al. [5].

The purpose of this work is to study the relationship between FHR and fetal breathing. This was done using precision noninvasive ultrasonic techniques capable of simultaneous detection and recording of the two parameters; thus, in order to do this, a multitransducer with TM-mode recorder was used.

This methodology permits a reliable measurement of FHR intervals during apnea and in the presence of fetal breathing.

\section{Materials and methods}

Fetal breathing movements (FBM) and FHR were simultaneously detected using a B-mode real-time scanner and a TM-mode recorder (Aloka SSD-200). Thus, it was possible to record from a selected line of multitransducer scanner onto photosensible

\section{Curriculum vitae}

MARIO CAMPOgRANDE was born in 1941 in Turin. Graduated from the Medical Faculty of the University of Turin in 1965 , specialized at the Departement of Obstetrics and Gynecology of the same University. Assistent at the Obstetrical and Gynecological Clinic; Senior Lecturer at the Obstetrical and Gynecological Pathology Institute of the University of Turin. Professor of Prenatal Medicine at the Postgraduate Turin School of Obstetrics and Gynecology. Main clinical and research interests are in the field of fetal monitoring, obstetrical ultrasounds, prenatal diagnosis, with training periods at Wien University and at King's College Hospital Medical School, London.

paper. The ultrasound system had two displays composed of the simultaneous observation in realtime scan and the TM-mode tracing. On B-mode scan the line for TM-recorder is selected and visible during the observation period. The transducer operated at a frequency of $2.5 \mathrm{MHz}$. The paper speed was $2.5 \mathrm{~cm}$ per second.

Analyses were performed on windows of ten seconds duration to show the mean heart interval, the standard deviation of the intervals and the mean absolute interval difference. Seventeen examinations were performed on fifteen normal women with singleton pregnancies between 36 and 
41 weeks gestation. The patients were examinated in semirecumbent position in the early afternoon between one and three o'clock p.m. Observation periods were between 30 and 60 minutes, giving an average of 38 minutes. Before the test placental localization, fetal presentation, position, biparietal diameter, and abdominal diameters were evaluated and found to be normal for each patient.

A basal section of fetal chest, often transversal, sometimes oblique including on the same line two distal and proximal points of the chest wall, and a clear heart signal (often interventricular septum or valvular structures) was selected and recorded in TM-mode for periods of 5 to 30 minutes (average of ten minutes). In this way on the same tracing, FBM and FHR were recorded, while the observation in real-time was continued.

Recording stopped when body fetal movements were present although the observation in real-time continued in order to reinstitute recording on photosensible paper when fetal body movements stopped.
Recordings with no clear FBM signals were eliminated, so that only TM-mode tracings with both FBM and heart activity were examinated. On photosensible paper FBM appeared as simultaneous proximal and distal sinusoidal wave forms corresponding to chest wall movements (in some parts of the tracing the distal chest wall is not so clearly identified) (Fig. 1).

In the periods of apnea sinusoidal wave forms were replaced by straight lines (Fig. 2).

Echocardiographic records were not always referable to an exact heart structure; however, they could be used for a sure and precise measure of beat-to-beat intervals. Fetal and transducer stability during the recording periods allowed the tracing to refer to continuous motion of the same heart structure as substantiated by the constant morphology of the tracing. By means of precision calipers, beat-to-beat intervals have been measured to the tenth of millimeter from consecutive echocardiographie wave from events. With the same method the rate of breathing has been studied.

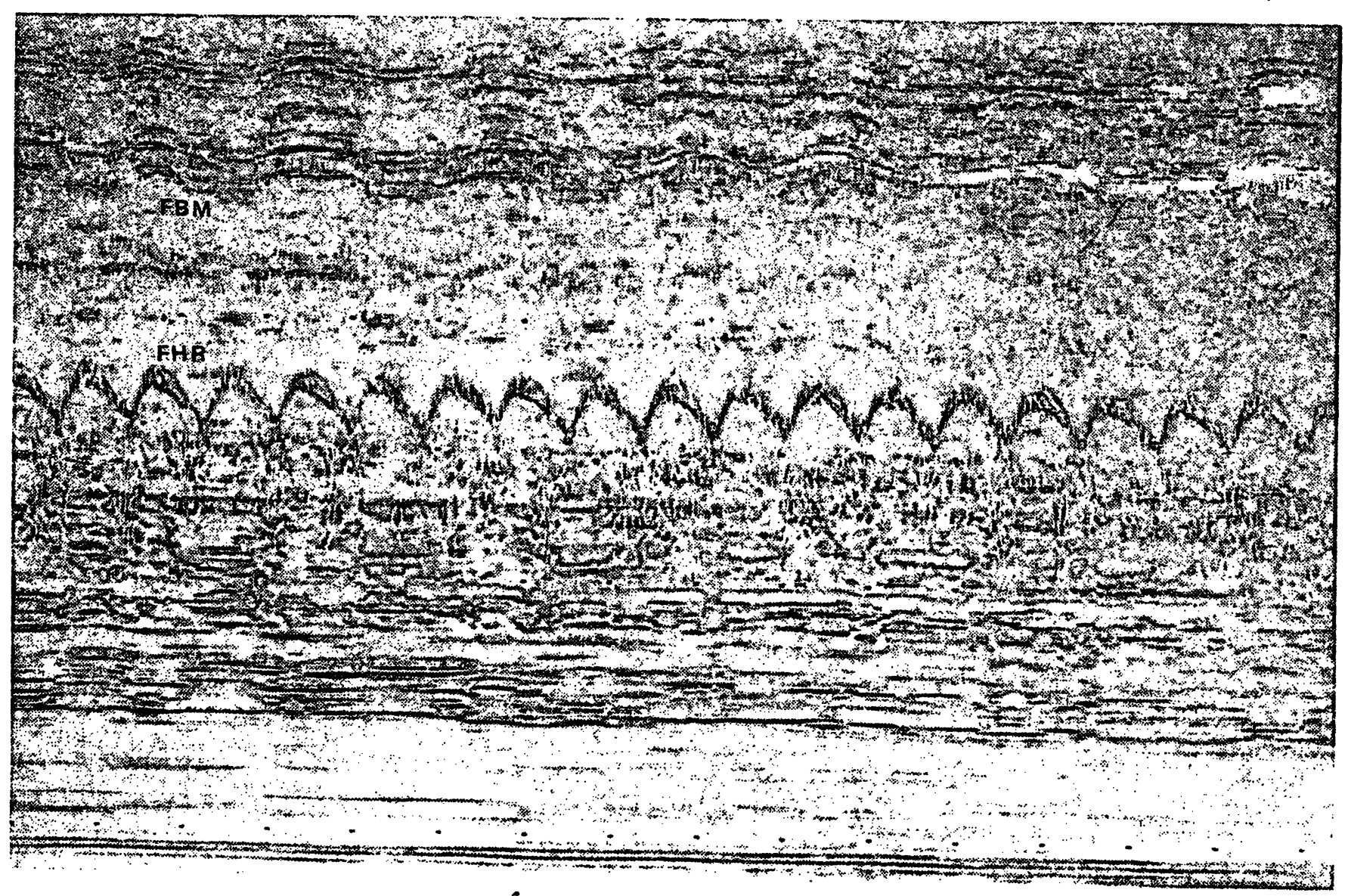

Fig. 1. TM-recording of chest walls and cardiac structures of fetus at term, during fetal breathing. FBM: excursions of chest walls FHR: cardiac waves 


\section{Results}

Records of FBM and FHR have been achieved in 12 of 17 observations made from 15 women. In 10 of the 12 patients, a good study of FHR beatto-beat intervals, was possible during both apnea and breathing. In two cases the heart tracing has been examined only in presence of FBM because these movements were present for the entire observation period.

One or more 10 second windows (equivalent to $25 \mathrm{~cm}$ of tracing) have been analyzed for a total of 260 seconds (equal to $650 \mathrm{~cm}$ of tracing). There were 16 periods of observation in the presence of FBM and 10 periods during apnea. Study of breathing movements evaluate the presence or absence of FBM, considering as apnea the absence of FBM for 6 seconds or more during episodes without gross fetal body movements.

FBM have been observed in 13 of the 17 recordings (76\%). The mean rate of fetal breathing movements during respiratory episodes was $55.04 \pm$ 12 breaths per minute.
Fetal cardiac activity has been studied using these parameters, as WHEELER et al. [14] have reported: 1) heart rate expressed as mean of interval beat-tobeat measured in msec,

2) long-term heart variability measured as standard deviation of intervals beat-to-beat (msec) (Tab. I), and

3) short-term heart variability measured as a mean of absolute interval difference expressed in msec (Tab. I).

The distribution of these measurements is shown in Tab. II.

Four hundred forty-nine intervals during fetal breathing activity and 214 intervals during apnoea have been studied. FHR was not significantly different in the periods of apnoea compared with the periods of breathing: Mean intervals were 435.03 $\pm 26 \mathrm{msec}$ during breathing and $438.90 \pm 41 \mathrm{msec}$ during apnea. The mean interval, with the onset of breathing decreased in 7 recordings and increased in 5 recordings and in one case remained equal. Both long-term and short-term variability in-

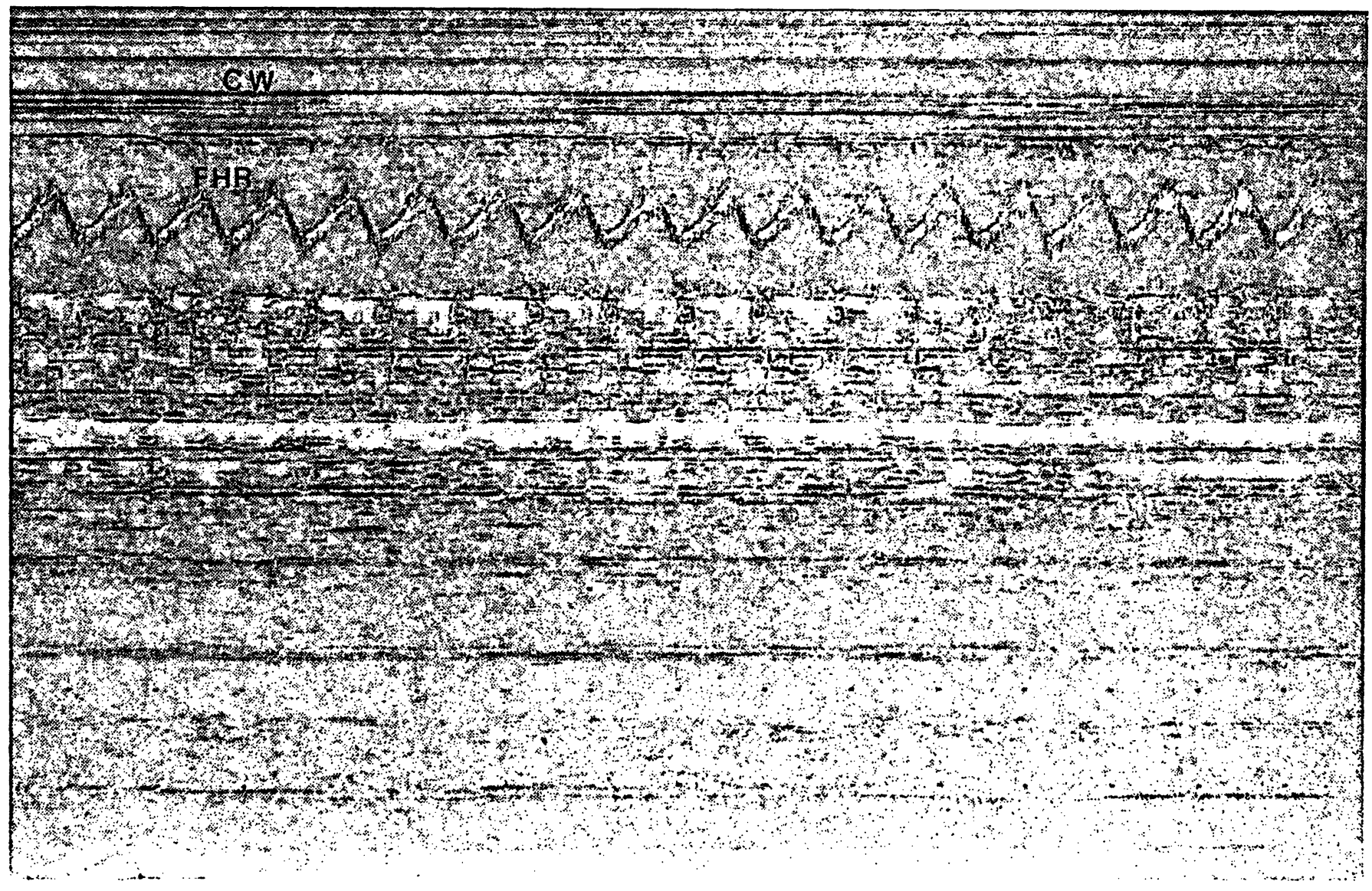

Fig. 2. TM-mode recording of chest walls and cardiac structures of fetus at term, during apnea periods.

CW: chest walls FHR: cardiac waves 
Tab. I. Expressions used to describe heart rate variability - WHEELER et al. [14]:

A) Long term variability

- Standard deviation of beat-to-beat intervals $\left(\mathrm{T}_{1}, \mathrm{~T}_{2}\right.$, etc.)

- Coefficient of variation of beat-to-beat intervals: i.e. $\frac{\mathrm{SD}}{\text { mean }}$

B) Short term variability

- Standard deviation of beat-to-beat interval differences: i.e. SD of $\left(T_{1}-T_{2}\right),\left(T_{2}-T_{3}\right)$, etc.

- Mean absolute interval difference:

i.e. mean of $\frac{T_{1}-T_{2}}{2}, \frac{T_{2}-T_{3}}{2}$, etc.

Tab. II. Analysis of FHR during periods of breathing and apnoea.

\begin{tabular}{llll}
\hline & $\begin{array}{l}\text { Breathing } \\
\text { (mean } \\
\pm \text { SD) }\end{array}$ & $\begin{array}{l}\text { Apnoea } \\
\text { (mean } \\
\pm \text { SD) }\end{array}$ & $\begin{array}{l}\text { Signifi- } \\
\text { cance }\end{array}$ \\
\hline Number of epochs & 16 & 10 & \\
Mean intervals & $435.03 \pm 26$ & $438.90 \pm 41$ & N.S. \\
SD intervals & $34.25 \pm 15$ & $24.64 \pm 4$ & p $<0.05$ \\
Mean absolute & $22.84 \pm 7$ & $12.76 \pm 4$ & p $<0.001$ \\
\hline
\end{tabular}

creased significantly in presence of FBM compared with the periods of apnea (Fig. 3). Long-term variability, in the presence of FBM, was $34.25 \pm$

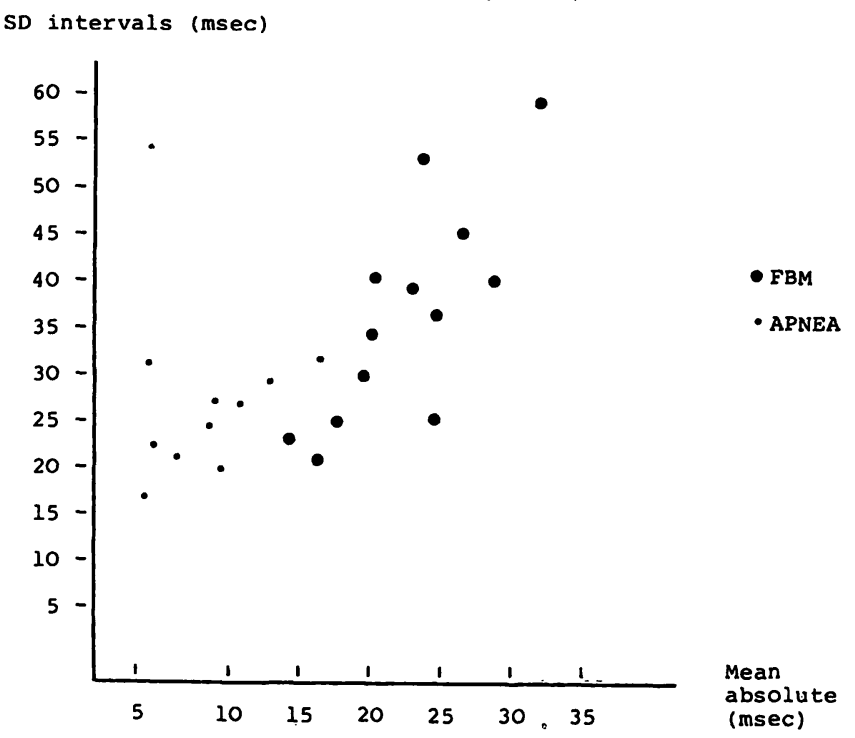

Fig. 3. SD intervals versus mean absolute difference inter. vals of FHR during FBM and during apnea periods.
15 and $24.64 \pm 4$ during apnea $(p<0.05-$ Student's test). Ten of the thirteen comparisons showed this increase.

Short-term variability (mean absolute interval difference) was $22.84 \pm 7$ during breathing and $12.76 \pm 4$ during apnea $(p<0.001$ - Student's test): Fetal breathing was associated with a significant increase in 11 of the 13 comparisons. FHR variability was essentially the same in the two women in which FBM were present during the entire observation period.

\section{Discussion}

The results of this study are similar to those found in preveious investigations by WHEELER et al. [13], and confirm an increase of short-term and long-term FHR variability in presence of FBM, although the increase is less significative for the latter. DAwEs et al. [5] had observed modifications of the short term variability only. TIMORTRITSCH et al. [12] also report modifications of FHR in presence of FBM. We believe it is possible that the method we have used is free from the problems that have been associated with the methodologies of these investigators. In fact, DAwEs [5] has suggested that the modifications recorded on tracings of fetal ECG as detected by WheEler et al. [13] and DAWEs et al. [5] could be dependent on change in the cardiac axis.

Recording FBM using a maternal abdomen transducer [12] may have some uncertainty as to the correct identification of breathing, and FHR as recorded by DOPPLER [12] may have some possible artifacts. The direct observation of cardiac activity in real-time with the concomitant recording of TM-mode tracing demonstrating a constant morphology allowed us to maintain that our measures of beat-to-beat intervals were reliable. In this work we have not had sufficient data to evaluate the observed FHR variability as a respiratory arrhythmia, and this question is under consideration now.

It is well-known that in extrauterine life cardiac and respiratory activity are ascribed to different mechanisms. 
A) cardio-respiratory reflexes originating from receptors located in the respiratory tract. The lung contains a variety of receptors: 1) receptors in the airways: inflaction of the lungs causes an acceleration of the heart, presumably by the activation of the pulmonary stretch receptors; 2) rapidly adapting receptors in the major bronchia connected to myelinated vagal afferents; 3 ) receptors in lung parenchyma connected to unmyelinated vagal afferents: Some of these receptors are located close to the pulmonary capillaries and they are activated by an increase in interstitial fluid volume in the lungs. A second type of receptor in lung parenchyma is connected with sympathetic nerves, and their function is unknown. There is an inhibitory reflex of the cardiovascular center (vagal nucleus);

B) reflexes originating from cardiovascular receptors. Three sets of receptors are activated by changes in pressure of the heart chambers: 1) receptors at the veno-atrial junction; 2) diffuse receptors network with unmyelinated vagal afferents; 3) diffuse receptors network with sympathetic afferents.

Increased filling of right atrium during inspiration activates the mechanoreceptors with resultant increase of sympathetic activity to the sinus node;
C) central irradiation of inhibitory impulse from the respiratory centers to the cardiovascular centers;

D) cardiovascular response to muscular contraction: The centers in the brain from motor cortex alter the output of the medullary cardiovascular centers.

Considering point $A$, in the fetus there is no stretching of the alveoli, because of the poor or absent fluid flow through the respiratory tract [3], although FBM could stimulate the other receptors present in the lung parenchyma, possibly also by increase in pulmonary blood flow. The cardiovascular receptors (point B), too, may be invocated: EIK-NES et al. [6] had observed an increase of inferior cava vein blood velocity and a decrease in umbilical vein flow velocity during inspiration.

Finally, we can suggest that in the fetus too, a flow of impulses from the respiratory centres (point C) to the cardiovascular centers is present, as central activation of diaphragm could alter the output of the medullary cardiovascular centers (point D).

\section{Summary}

Human fetal breathing movements (FBM) and cardiac activity (FHR) have been studied with a real-time B-mode ultrasound system and recorded in TM-mode, with a multitransducer. It was so possible to record simultaneously FBM and FHR on photosensible paper Seventeen examinations have been performed on 15 normal women between 36 and 41 weeks of gestation. Observation periods work between 30 and 60 minutes, giving an average of 38 minutes. In 10 patients a study of fetal beat-to-beat intervals both during breathing and during

Keywords: FBM, fetal breathing, fetal heart rate. apnoea periods has been possible. In two more cases the study was performed only in presence of FBM.

Fourhundred forty-nine beat-to-beat intervals during fetal breathing activity and 214 intervals during apnea have been studied. FHR was not significantly different in the periods of apnea compared with the periods of breathing.

Long-term variability increased significantly $(p<0.05)$ in presence of FBM compared with the periods of apnoea as did short-term variability $(p<0.001)$.

\section{Zusammenfassung}

Kurż- und langfristige Veränderung im Zusammenhang mit der fetalen Atmung

Die fetalen Atembewegungen (FBM) und die fetale Herzaktivität (FHR) wurden mit einem real-time B-mode Instrument untersucht und von einer Multisonde mittels
TM-mode aufgenommen. So war es möglich, gleichzeitig FBM und FHR auf fotoempfindliches Papier aufzunehmen.

17 Aufnahmen wurden von 15 gesunden Frauen zwischen der 36. und 41. Schwangerschaftswoche gemacht. Die Be- 
obachtungszeiten lagen zwischen 30 und 60 Minuten, die Durchschnittszeit lag bei 38 Minuten. Während der Atemund Apnoeperioden war in 10 Fällen eine Intervalluntersuchung zwischen den Herzschlägen möglich. In zwei Fällen wurde die Untersuchung nur bei FBM durchgeführt. Während der fetalen Atemtätigkeit wurden 449 Intervalle und während der Apnoeperioden wurden 214 Intervalle registriert. Verglichen mit den Atemperioden zeigte die fetale Herzfrequenz keine wesentlichen Unterschiede während der Apnoeperioden.

Verglichen mit den Apnoeperioden stieg die langfristige Veränderung beim FBM $(\mathrm{p}<0.05)$ und auch die kurzfristige Veränderung $(p<0.001)$ bedeutend an.

Schlüsselwörter: FBM, FHR, kurz- und langfristige Veränderungen.

\section{Résumé}

Des changes en variabilité cardiaque associé aves les mouvements respiratoires du foetus

Les mouvements respiratories du foetus (FBM) et l'activité cardiaque (FHR) on été étudiés et enregistrés par un apparail d'ultrasons de type $B$ à temps réel et par un appareil de TM-mode. Ainsi, il était possible d'enregistrer simultanéement l'activité respiratoire et cardiaque fœtale sur un papier photosensible.

i. Chez 15 patientes enceintes entre la 36ème et la 41ème semaine de grossesse 17 observations ont été faites. Les periodes d'observation duraient de 30 à 60 minutes, avec un moyen de 38 minutes. En 10 cas, il était possible de recevoir une bonne étude des intervalles cardiaques du

Mots-clés: FBM, FHR, mouvements respiratoires du fœus.

\section{Bibliography}

[1] ADAMSONS, K., R. E. MYERS, A. COMAS-URRUTIA: Fetal breathing movements as a cause of beatto-beat variability of FHR. Gynecol. Invest. 7 (1976) 21

[2] COMROE, J. H.: Fisiologia della respirazione. Roma Il Pensiero Scientifico 1975

[3] DAlton, K. J., G. S. DAWES, I. PATriCK: Diurnal, respiratory and other rhythms of fetal heart rate in lambs. Amer. J. Obstet. Gynec 127 (1977) 414

[4] DAWES, G. S.: Breathing before birth in animals and man. New Engl. J. Med. 7 (1974) 557

[5] DAWES, G. S., G. H. A. VISSER, J. D. S. GoODMAN, D. H. LEVINE: Numerical analysis of the human fetal heart rate: modulation by breathing and movement. Amer. J. Obstet. Gynec. 140 (1981) 535

[6] EIK-NES, S. H., K. MARSAL, A. O. BRUBBAK, M. ULSTEIN: Ultrasonic measurements of human fetal blood flow in aorta and umbelical vein. Influence of fetal breathing movements. In press (1981)

[7] FOURON, J., Y. KORCAZ, B. LEDUC: Cardiovascular changes associated with fetal rhesus monkeys. Amer. J. Obstet. Gynec. 119 (1975) 868

[8] HAINSWORTH, R., C. KIDD, R. J. LINDEN: Cardiac receptors. Cambridge University Press 1979

[9] JORGENSEN, J., S. H. EIK-NES, K. MARSAL: Fetal blood flow due to fetal breathing movements. Excerpta Medica 4th Europ. Congress Ultr. Med. 1981 fœtus, soit au moment des mouvements respiratoires, soit en apnée. En 2 cas, l'étude n'était possible qu'au moment du FBM.

Pendant les mouvements respiratoires du fœtus, 449 intervalles ont été enrregistrés, pendant que le fœus était apnéique, 214 intervalles ont été enregistrés.

$\mathrm{La}$ fréquence cardiaque fœtale n'était pas différente significativement en présence des mouvements respiratoires comparée avec celle des periodes d'apnée.

La long-term variability était augmentée significativement ( $p<0.05$ ) au moment de la respiration fœtale comparée aux periodes d'apnée, ainsi que la short-term variability $(\mathrm{p}<0.001)$.

[10] Martin, C. B., Y. MURATA, R. H. PETRIE, J. T. PARER: Respiratory movements in fetal rhesus monkeys. Amer. J. Obstet. Gynec. 119 (1974) 939

[11] SHEPHERD, J. T., P. M. VANHOUTTE: The human cardiovascular system. Raven Press, New York 1979

[12] TIMOR-TRITSCH, I., I. ZADOR, R. H. HERTZ, M. G. ROSEN: Human fetal respiratory arrhythmia. Amer. J. Obstet. Gynec. 127 (1977) 662

[13] WHEELER, T., G. GENNSER, R. LINDVALL, A. J. MURRILLS: Changes in the fetal heart rate associated with fetal breathing and fetal movements. Brit. J. Obstet. Gynec. 87 (1980) 1068

[14] WHEELER, T., E. COOKE, A. J. MURRILlS: Computer analysis of fetal heart rate variation during normal pregnancy. Brit. J. Obstet. Gynec. 86 (1979) 186

[15] YAO, A. C., J. LIND: Current concepts on respiratory and circulatory adaptation on the fetus and newborn. Europ. J. Obstet. Gynecol. Reprod. Biol. 6 (1976) 347

Received October 30, 1981. Revised January 11, 1982. Accepted March 17, 1982.

Dr. Mario Campogrande

Obstetrical and Gynaecological

Pathology Institute

University of Turin

Via Ventimiglia, 3

I-10126 Torino/Italy 